\title{
CORPORATE SOCIAL RESPONSIBILITY AND BRAND MANAGEMENT: EVIDENCE FROM CARROLL'S PYRAMID AND TRIPLE BOTTOM LINE APPROACHES
}

\author{
Dalia ŠTREIMIKIENE ${ }^{1 *}$, Rizwan Raheem AHMED ${ }^{2}$ \\ ${ }^{1}$ Faculty of Public Governance and Business, Mykolas Romeris University, \\ Ateities 20, LT 08303 Vilnius, Lithuania \\ ${ }^{2}$ Faculty of Management Sciences, Indus University, Gulshan-17, \\ Karachi-75300, Pakistan
}

Received 13 September 2020; accepted 03 January 2021

\begin{abstract}
The objective of this research is to evacuate the relationship between CSR initiatives and organizational performance. Additionally, the undertaken research examines the impact of brand image and brand awareness as mediators and corporate image as the moderator between CSR initiatives and organizational performance. We employed a modified conceptual framework derived from the Triple bottom line and Carroll's pyramid models. The data was analyzed through the structural equation model by using confirmatory and exploratory factor analyses and conditional process approach for examining the direct, mediating, and moderating hypothesized relationships. The undertaken study's outcomes demonstrated that the ethical, philanthropic, and sustainable dimensions positively and significantly influence organizational performance. Similarly, the mediation analysis suggested that the brand image and brand awareness are the potent mediators in an association between ethical, philanthropic, and sustainable dimensions and organizational performance. Findings further demonstrated that corporate image as a moderator has strong impact between exogenous factors and organizational performance. The undertaken study has important theatrical and managerial implications that provide value additions for both researchers and industry practitioners.
\end{abstract}

Keywords: corporate social responsibility, environment, brand management, brand image, brand awareness, corporate image, Carroll's pyramid, triple bottom line approach.

JEL Classification: C12, L1, M14, Q2.

\section{Introduction}

Now, in the day's competitive business environment, corporate social responsibility is one of the most imperative business strategies for brand management to achieve sustainable longterm growth and organizational performance. According to Alrubaiee et al. (2017), Flam-

${ }^{\star}$ Corresponding author. E-mail: dalia.streimikiene@lei.lt

Copyright (c) 2021 The Author(s). Published by Vilnius Gediminas Technical University

This is an Open Access article distributed under the terms of the Creative Commons Attribution License (http://creativecommons. org/licenses/by/4.0/), which permits unrestricted use, distribution, and reproduction in any medium, provided the original author and source are credited. 
mer and Luo (2017), and Baumgartner (2014), several organizations have adopted different CSR initiatives as a unique business strategy to achieve long-term growth and competitive advantage. According to Lu et al. (2020a), Ahmed et al. (2017), Aguinis and Glavas (2013), and Almeida and Coelho (2019), the creative environmental corporate strategies are connected with CSR practices; companies could achieve the demand of the competitive market by embracing CSR initiatives as a corporate strategy for long-term sustainable growth, and competitive advantage. The research scholars have proposed several CSR models in which the Triple bottom line (TBL) approach and Carroll's pyramid of CSR are the most prominent models as a business strategy for sustainable and long-term growth (Lu et al., 2020b; Carroll, 2008; Cho et al., 2017; Elkington, 1999). Previous literature has substantiated the rivalry amongst the firms, and addressed a dire requirement to establish marketable, sustainable growth, innovative process, and authentic green brands. Thus, they integrate CSR initiatives into business strategies to compete with other brands (Ahmed et al., 2017; Cretu \& Brodie, 2007). According to Chen et al. (2019), Lu et al. (2020b), Martínez et al. (2014), previous studies have conducted on the environmental, and organizational benefits regarding the CSR practices as a business strategy. However, there is still room to carry out further research to comprehend CSR initiatives' benefits as a business strategy for brand awareness, brand image, and brand management. Consequently, the brand management has become an imperative measure to enhance the competitiveness, and customers are more associated with the brand, known as the brand image and brand awareness (Abid et al., 2020; Ahmed et al., 2017; Grönroos, 2007). The brand image is a vital element and most significant marketing strategy that affects both subjective and objective extents of consumer's insights (Rahman et al., 2019; Martínez et al., 2014). Several studies have demonstrated a positive influence of CSR initiatives on the brand image; studies further suggested that the applied CSR initiatives and consumer's perception regarding the brand awareness and brand image are interrelated (Boonpattarakan, 2012; Casado-Diaz et al., 2014; Werther \& Chandler, 2005).

The risen skepticism regarding the CSR in the minds of customers led towards the negative perception for brands due to the adverse feeling about the CSR activities of an organization. Therefore, organizations need to be cautious and vigilant while devising CSR campaigns (Park, 2019; Hwang \& Lyu, 2018; Flammer \& Luo, 2017). If an organization's behavior seems irresponsible during CSR campaigns, then the brand image and corporate image could be severely damaged (Calabrese \& Lancioni, 2008; Dawood, 2019; Bhattacharya \& Sen, 2004). Thus, it is imperative to incorporate suitable CSR strategies to enhance corporate image, brand awareness, and brand image. Bearing in mind, the brand image and brand awareness are among the most significant facets of a business strategy while making effective CSR campaigns (Lho et al., 2019; Ahmed et al., 2017). The studies are limited to CSR initiatives' influence on brand image and brand awareness in South Asian countries, thus it is imperative to study this topic. The companies can devise better CSR strategies by comprehending the customers' attitudes and reactions regarding the CSR initiatives. The undertaken research outcomes can be generalizable across the manufacturing and services sectors of China, India, Pakistan, and Bangladesh. According to Dawood (2019), Ahmed et al. (2017), and Dyck et al. (2019), the existing literature has a tremendous gap regarding the role of CSR initiatives as a corporate environmental strategy for enhancing corporate image, brand image, and brand awareness in the perspective of developing economies of South Asia (Lee, 2020; 
Galbreath, 2010; Domi et al., 2019; Dawood, 2019). Therefore, this research study has derived a modified conceptual framework regarding the CSR business strategy and evaluates brand image and brand awareness as mediators and brand image as a moderator of organizational performance. The undertaken study examines the impact of ethical, philanthropic, and sustainable dimensions as CSR practices, and their influence on firm's performance with brand management for services and manufacturing sectors of China, India, Pakistan, and Bangladesh. The undertaken study has incorporated a tailored model taking from Triple bottom approach, and Carroll's pyramid of CSR as an effective environmental corporate strategy for the sustainable growth, and long-term competitive advantage of brands was examined from the perspective of manufacturing and services sectors of developing countries. The undertaken study not only evaluates the modified conceptual framework of CSR initiatives that are based on Carroll's pyramid (ethical \& philanthropic dimensions) and Triple bottom line approach (sustainable dimension) but also evaluates the impact of brand image and brand awareness as mediators and also incorporated corporate image as a moderating factor in an association of firm's performance as a dependent factor. Thus, in this way, we have derived a unique business model of CSR initiatives and empirically tested through SEM-based modeling. The outcomes of the undertaken study are beneficial to the business managers for devising business strategies and future directions for the services and manufacturing sectors of China, India, Pakistan, and Bangladesh. This research is unique in a way that it develops the adapted conceptual model with the emphasis of CSR business strategies and its impact on marketing elements.

This paper's remainder comprises of review of literature as section two - material and methods as section three demonstrated the findings \& results - section four includes discussions - and section five contains on conclusion, and followed by theatrical and practical implications. In the end, we have discussed the delimitations, limitations, and potential avenues of future studies.

\section{Review of literature}

Several research studies have already been conducted on CSR initiatives as a business strategy. Still, very few studies are carried out on the relationship between CSR initiatives and brand management, especially in south Asian economies. According to Carroll (1979), the early research studies regarding the impact of CSR related activities were carried out in the 1950s. The first documented definition was coined by Bowen (1953), however, according to Park (2019), Hoque et al. (2018), and Xuan and Teal (2011), modern studies amid CSR practices as an environmental corporate strategy are based on Carroll (2004) and Windsor (2001). However, a complete definition of CSR and CSR practices as an environmental business policy for sustainable growth, and long-term competitive advantage of a firm was discussed in detail in the 2000s (Han et al., 2019; Flammer \& Luo, 2017; Kuo et al., 2016).

\subsection{Organizational performance}

According to Chen et al. (2018), and Gardberg et al. (2019), several research studies have been conducted regarding the concept and models of CSR initiatives and organizations' responsibilities. These organizational CSR activities fulfill a business's numerous obligations for 
distinctive stakeholders, for instance, shareholders, employees, customers, and communities. The outcomes of CSR related activities provide sustainable competitive advantage, and longterm growth to the organizations (Han et al., 2019; Lu et al., 2020b). According to Lu et al. (2020a), and Coles et al. (2013), stakeholders anticipate from the organizations to fulfill their ethical, legal, philanthropic, and economic obligations, which are essential for the competitive advantage, and long-term growth. Thus, by accomplishing such obligations as a social entity, organizations can enhance their ties with stakeholders, and at the same time also increase their long-term sustainable performance through competitive advantage (Hwang \& Lyu, 2018; Kuo et al., 2016). Several researches have proven an affirmative connection between CSR initiatives and long-term sustainable organizational performance (Lu et al., 2020b; Galant \& Cadez, 2017). The undertaken study has incorporated a novel conceptual framework in which ethical, philanthropic, and sustainable dimensions are taken as CSR initiatives, and evaluate the performance through the brand image, brand awareness, and corporate image.

\subsection{Carroll's pyramid of corporate social responsibility}

Before the CSR pyramid of Carroll, the concept of CSR had included an enormous variety of ethical, economic, legal, and philanthropic aspects. Still, it was discretionary to place any element anywhere according to the business situation without any sequence (Carroll, 1991). The first time, Carroll's (1979) has given proper hierarchical arrangement to these dimensions, and he termed that order as Carroll's pyramid of CSR. In his CSR pyramid, he had given the most priority to the economic dimension due to its importance, GDP contribution, employment opportunities, and shareholders' wealth. He claimed if an economic activity does not function properly, then other dimensions of CSR are irrelevant. According to Carroll (1979), the second critical dimension is legal because if the firm does not perform according to the government's rules and regulations, it can have a proper and timely function. Similarly, he ranked ethical at number three and philanthropic at number four. Thus, in this way, Carroll (1979) devised a pyramid of CSR. So far, this pyramid has remained very valid, and most of the organizations make their business strategies based on this pyramid. All the companies are making a profit by selling goods and services. Thus, the economic dimension is inevitable for every company, similarly, and the organization operates under specific laws and regulations. Therefore, the company has to abide by that legal framework. Society has a dire need for two other responsibilities: ethical and philanthropic; these two dimensions are mainly important for corporate image, brand image, and brand awareness (Park, 2019; Hwang \& Lyu, 2018; Flammer \& Luo, 2017). Therefore, we have selected ethical and philanthropic dimensions from the CSR pyramid of Carroll for the undertaken research.

\subsection{Triple bottom line (TBL) approach}

The triple bottom line (TBL) approach was developed and proposed by Elkington (1999); it was a substantial contribution in CSR, the TBL also known as a 3Ps model, which is mainly dedicated to the sustainability dimension. The TBL model emphasizes the profitability issues and provides directions to assess the influence of business on social and environmental aspects. The TBL model of Elkington (1999) highlights the organizational performance 
besides the interrelated elements of People (social), profit (financial), and planet (environment) for the long-term sustainable development. Profitability is the prime objective of any organization, but environmental issues, employees, customers, and communities are equally important. Thus, the TBL model measures the organization's sustainability, environment, community, and industrial sector (Li et al., 2020; Jeon \& An, 2019; Zulfiqar et al., 2019; Coles et al., 2013; Slapper \& Hall, 2011). Hence, the undertaken study has incorporated the sustainable dimension as a CSR business strategy in a modified conceptual framework from the perspective of South Asia's developing economies.

\subsection{Brand image}

According to Abid et al. (2020) and Martínez et al. (2014), brand image enhances the company's competitive advantage, and CSR initiatives also drive the emotional feature of brand image. If the CSR initiatives devise the company's positioning strategy, then the CSR initiatives filled the core values of an organization ( $\mathrm{Du}$ et al., 2010). The CSR initiatives as a business strategy not only enhances the corporate image but also increase the brand image (Hussain \& Ahmed, 2020; Lho et al., 2019; Werther \& Chandler, 2005). According to Malik et al. (2011), the CSR initiatives as a business strategy protect brands from the rival brands; moreover, the brand image is a vital marketing instrument across services and manufacturing sectors. However, according to the previous literature, there is an ambiguity for measuring the brand image due to multidimensionality. Several studies evaluated CSR initiatives' impact on the brand image; these studies confirmed a positive association between CSR as a business strategy and brand image (Rahman et al., 2019; Dawood, 2019). According to Keller (1993), the brand image could be measured through symbolic, experiential, functional, and attitude aspects. This measurement is more holistic due to its broad coverage for both services and manufacturing sectors. Several studies demonstrated that CSR initiatives increase the brand image and organizational performance (Yang \& Basile, 2019; Ahmed et al., 2017; Wu \& Wang, 2014).

\subsection{Brand awareness}

Several studies have demonstrated that corporate distinctiveness has numerous corporate culture measurements, brand loyalty, and brand awareness (Demirel, 2020; Ahmed et al., 2017; Balmer \& Greyser, 2006; Melewar \& Karaosmanoglu, 2006). According to Nan and Kwangjun (2007), Lewis (2003), and Kitchin (2003), the cause-related marketing, attitude, and perceptions of the corporate image are the main interest of customer that enhances the brand awareness and brand loyalty. According to Dawood (2019) and Rahman et al. (2019), the CSR initiatives are the drivers of enhancement for corporate brand and brand awareness. Moreover, CSR activities and the organization's marketing and business strategies build a synergistic effect on brand awareness (Lho et al., 2019; Rahman et al., 2019). The philanthropic measurement of organizational values and culture is imperative for building a stronger bond with its brands; for example, socially responsible organizations have a strong competitive advantage (Maignan et al., 2005; Marín et al., 2009). The organization with strong CSR values with a triple bottom line approach offers an instrument to build a novel conceptual model for brand awareness and corporate branding (Abid et al., 2020; Kayaman \& Arasli, 2007). 


\subsection{Corporate image}

The CSR initiatives increase the positive corporate image; the core values, mission, strategy, and culture should be integrated into the CSR business strategies for a more significant corporate image (Lu et al., 2019; Bronn \& Vrioni, 2011). According to Martínez et al. (2014) and Suki and Suki (2019), a customer's impression amid a firm in which it works in a manner for the firm's positive perception is known as the corporate image. According to $\mathrm{Wu}$ and Wang (2014) and Tang (2007), corporate image increases the meaningful impact in customers' minds regarding the organization's products and services that enhance the long-term sustainability and competitive advantage. The distinctive feature of a firm as a brand, belief system, design, name, brand perception, and services, in which an organization interact to its customer is also recognized as corporate image (Kang \& Atkinson, 2019; Longo et al., 2005; Richard \& Zhang, 2012). The company's brand image is called the corporate image, which has intangible values that also substantiated the brands and interacted with the long-term sustainable organization performance and competitive advantage. According to Lai et al. (2010), and Singh and Saini (2016), the corporate image is an invisible resource and asset of an organization, which cannot be imitated, thus, corporate image lead the company towards the long-term financial and sustainable performance. Preceding literature exhibited a positive corporate image established the brand image of its brands compared to the competitors (Han et al., 2019; Chang et al., 2015; Farid et al., 2019). The undertaken research integrates CSR initiatives' corporate image in a modified conceptual framework and evaluates the organizational performance.

\subsection{Theoretical framework and hypotheses development}

We have derived our theoretical and conceptual framework from the previous literature and theories, the CSR initiatives based on the Triple bottom line approach, and Carroll's pyramid of CSR model (Figure 1). We have taken two crucial measurements of Carroll's pyramid, for instance, philanthropic \& ethical (Lu et al., 2020b; Carroll, 1979), and the sustainable dimension of CSR was incorporated from the Triple bottom line (TBL) model (Slapper \& Hall, 2011; Ottman, 2011). Thus, in our modified model, we have considered ethical, philanthropic, and sustainable dimensions as independent variables. We have taken brand image and brand awareness as mediators, and also incorporated corporate image as a moderating factor in a relationship of independent variables and firm's performance as a dependent variables in the services and manufacturing sectors of China, India, Pakistan, and Bangladesh. Thus, after a detailed evaluation of preceding literature, and theories, we have framed the following hypotheses.

\subsubsection{Direct hypothesized relationship}

$\mathrm{H1}$ : Ethical dimension of corporate social responsibility has a positive and significant impact on organizational performance.

$\mathrm{H} 2$ : Philanthropic dimension of corporate social responsibility has a positive and significant impact on organizational performance. 


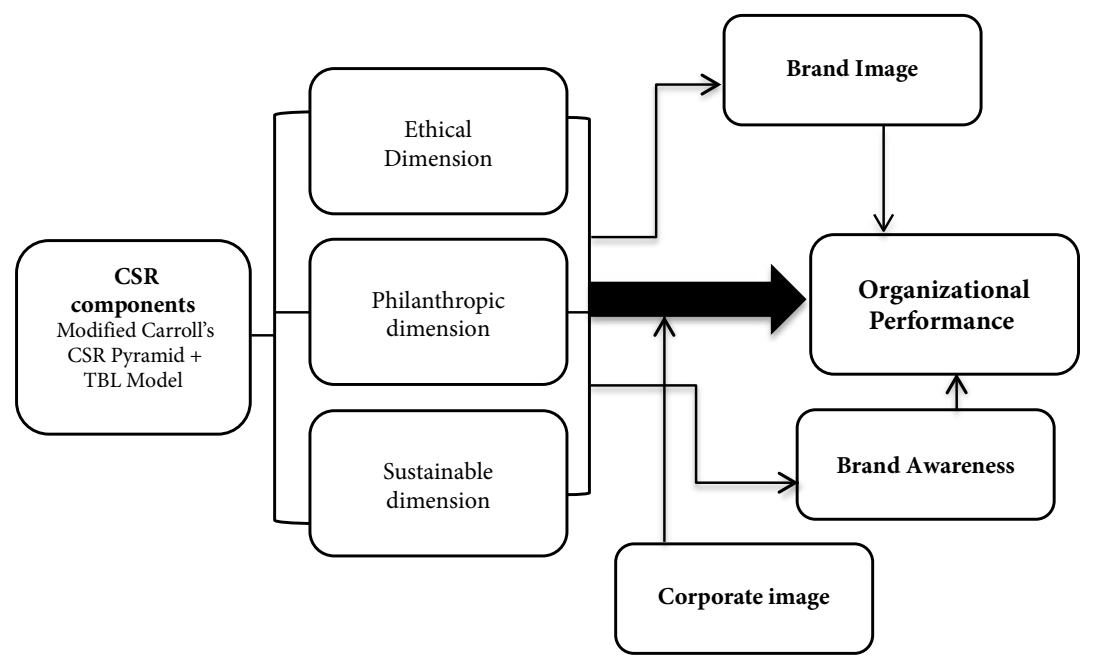

Figure 1. Conceptual framework of the undertaken research

H3: Sustainable dimension of corporate social responsibility has a positive and significant impact on organizational performance.

\subsubsection{Hypothesized mediating relationship}

H4A: Brand image has a significant mediating impact between the ethical dimension of CSR and organizational performance.

H4B: Brand image has a significant mediating impact between the philanthropic dimension of CSR and organizational performance.

H4C: Brand image has a significant mediating impact sustainable dimension of CSR and organizational performance.

H5A: Brand awareness has a significant mediating impact between the ethical dimension of CSR and organizational performance.

H5B: Brand awareness has a significant mediating impact between the philanthropic dimension of CSR and organizational performance.

H5C: Brand awareness has a significant mediating impact between the sustainable dimension of CSR and organizational performance.

\subsubsection{Hypothesized moderating relationship}

H6A: Corporate image has a significant moderating impact between the ethical dimension of CSR and organizational performance.

H6B: Corporate image has a significant moderating impact between the philanthropic dimension of CSR and organizational performance.

H6C: Corporate image has a significant moderating impact between the sustainable dimension of CSR and organizational performance. 


\section{Material and methods}

\subsection{Research design and measures}

We have employed deducted research, and we have formulated modified theoretical and conceptual models and framed hypotheses on the basis of previous literature. The deductive research is very closely linked to the quantitative and positivistic approaches (Saunders et al., 2009). The quantitative method is useful because the undertaken research is cross-sectional, moreover, this approach shows the positivistic philosophy and quantitative analysis exhibits an extensive and broad exposure (Ahmed et al., 2019). The modified items of philanthropic and ethical dimensions are developed from previous literature, for instance, Lu et al. (2020b), Carroll (2016), and Gardberg et al. (2019). The adapted items of the sustainable dimension of CSR have been considered from Slapper and Hall (2011), Ottman (2011), Kuo et al. (2016), and Coles et al. (2013). The modified items of the brand image have been taken from preceding researches, for instance, Martínez et al. (2014), Du et al. (2010), Dawood (2019), Lho et al. (2019), Wu and Wang (2014), and Werther and Chandler (2005). The modified items of brand awareness have been derived from previous studies (Ahmed et al., 2017; Balmer \& Greyser, 2006; Melewar \& Karaosmanoglu, 2006; Nan \& Kwangjun, 2007). The modified items of the corporate image have been derived from previous literature such as Lu et al. (2020b), Suki and Suki (2019), Richard and Zhang (2012), Singh and Saini (2016), and Han et al. (2019). The modified items of organizational performance have been taken from Han et al. (2019), Lu et al. (2020a), Hwang and Lyu (2018), and Galant and Cadez (2017).

\subsection{Sampling strategy and data collection}

For the undertaken study, we employed adapted structured 5-point Likert scales questionnaire; we collected data from senior and middle cadre managers of services and manufacturing sectors of China, India, Pakistan, and Bangladesh. We have used quota sampling to get suitable responses from each country according to their economic strength. We got 312 responses from China, 221 responses from India, 140 responses from Pakistan, and 123 responses from Bangladesh. We have used social media, especially LinkedIn, for gathering information and then collected data through personal emails. Moreover, we used companies' websites to obtain managers' emails and then asked for the survey. In the segregation of services and manufacturing companies, there were 413 companies belong to the manufacturing sectors. However, the rest of the 383 belong to China, India, Pakistan, and Bangladesh. We had floated 900 survey forms but received 796 responses that were filled. Therefore, the response rate was 88.44\%, which quite satisfactory (MacCallum et al., 1999; Comrey \& Lee, 1992).

\subsection{Data analyses and estimations techniques}

We have used several statistical techniques for data analysis and estimation; first, we employed descriptive statistics to know the variables' essential characteristics. Since we used a modified conceptual framework, we employed both exploratory and confirmatory factor analyses. For the selection of modified items and constructs, we used exploratory factor analysis (EFA) in which we used rotated component matrix, average extracted variance, Bartlett's \& Kaiser Meyer Olkin (KMO), total variance explained procedures for the selection 
of items and constructs (Ahmed et al., 2019). We also used confirmatory factor analysis (CFA) to evaluate items and constructs, which were adopted from previous literature and theories. In CFA, we used measurement and structural hypothesized models and assessed through different fit-indices (Byrne, 2009; Hair et al., 2010). For direct \& indirect (mediation \& moderation) hypothesized relationship, we employed conditional process technique (Hayes \& Rockwood, 2020).

\subsection{Respondents' profile}

The findings of Table 1 demonstrated the demographic statistics depicted in our sample data; there were $448(56.3 \%)$ males and 348(43.7\%) females. Findings further revealed that there were $452(56.8 \%)$ respondents were single, $319(40.1 \%)$ were married; however, $25(3.1 \%)$ respondents were divorced. Table 1 further demonstrated that there were $281(35.3 \%)$ respondents belonged to the age brackets of 20-30 years, $173(21.7 \%)$ belonged to $30-40$ years, $106(13.3 \%)$ belonged to $40-50$ years, $129(16.2 \%)$ belonged to $50-60$ years, and $107(13.4 \%)$ respondents belonged to more than 30 years. Similarly, the qualification statistics showed

Table 1. Demographic profile of respondents

\begin{tabular}{|c|c|c|c|}
\hline \multicolumn{2}{|r|}{ Demographics } & Frequency & Percent \\
\hline \multirow{2}{*}{ Gender } & Male & 448 & $56.3 \%$ \\
\hline & Female & 348 & $43.7 \%$ \\
\hline \multirow{3}{*}{ Marital Status } & Single & 452 & $56.8 \%$ \\
\hline & Married & 319 & $40.1 \%$ \\
\hline & Divorced & 25 & $3.1 \%$ \\
\hline \multirow{5}{*}{$\begin{array}{l}\text { Age } \\
\text { (In Years) }\end{array}$} & $20-30$ & 281 & $35.3 \%$ \\
\hline & $30-40$ & 173 & $21.7 \%$ \\
\hline & $40-50$ & 106 & $13.3 \%$ \\
\hline & $50-60$ & 129 & $16.2 \%$ \\
\hline & More than 60 & 107 & $13.4 \%$ \\
\hline \multirow{4}{*}{ Education } & Graduation & 353 & $44.3 \%$ \\
\hline & Post Graduation (Local) & 257 & $32.3 \%$ \\
\hline & Post Graduation (Foreign) & 118 & $14.8 \%$ \\
\hline & Ph.D. degree & 68 & $8.5 \%$ \\
\hline \multirow{5}{*}{$\begin{array}{l}\text { Experience } \\
\text { (In Years) }\end{array}$} & $1-5$ & 209 & $26.3 \%$ \\
\hline & $5-10$ & 238 & $29.9 \%$ \\
\hline & $10-15$ & 105 & $13.2 \%$ \\
\hline & $15-20$ & 110 & $13.8 \%$ \\
\hline & More than 20 & 134 & $16.8 \%$ \\
\hline \multirow{5}{*}{$\begin{array}{l}\text { Income } \\
\text { (In USD 000) }\end{array}$} & $2-5$ & 138 & $17.3 \%$ \\
\hline & $6-9$ & 350 & $44.0 \%$ \\
\hline & $10-13$ & 166 & $20.9 \%$ \\
\hline & $14-17$ & 88 & $11.1 \%$ \\
\hline & More than 18 & 54 & $6.8 \%$ \\
\hline & Total - N & \multicolumn{2}{|c|}{796} \\
\hline
\end{tabular}


that there was 353(44.3\%) respondents acquired graduation degrees, 257(32.3\%) had local post-graduation degrees, $118(14.8 \%)$ acquired foreign post-graduation degrees, and $68(8.5 \%)$ respondents acquired Ph.D. degrees. The experience data of respondents revealed that there was 209(26.3\%) respondents possessed 1-5 years working exposure, 238(29.9\%) acquired 5-10 years exposure, $105(13.2 \%)$ possessed 10-15 years, $110(13.8 \%)$ respondents held 15-20 years experience, and 134(16.8\%) possessed higher than 20 years working exposure. In terms of income of respondents, there were $138(17.3 \%)$ had an income bracket of $2 \mathrm{~K}-5 \mathrm{~K}$ in US dollars, 350(44.0\%) respondents earning from 6K-9K per month. However, $166(20.9 \%)$ respondents were earning $10 \mathrm{~K}-13 \mathrm{~K}$ per month, $88(11.1 \%)$ respondents were earning $14 \mathrm{~K}-17 \mathrm{~K}$, and 54(6.8\%) respondents had an income of more than $18 \mathrm{~K}$ US dollars per month, here the " $K$ " represents for the values in " 000 ".

\section{Estimations and results}

\subsection{Descriptive statistics}

We have employed descriptive statistics such as skewness, kurtosis, and standard deviation to evaluate variables' fundamental features. The normality pattern of the data is also a prerequisite for using the parametric statistical model such as SEM-based multivariate approach (Ahmed et al., 2019; Huang et al., 2004). The findings of Table 2 demonstrated that readings of skewness \& standard deviation are ranging between \pm 1.5 , and kurtosis lies between \pm 3 . Thus, it is confirmed the normality of data of all the constructs (Hair et al., 2010).

Table 2. Descriptive statistics

\begin{tabular}{|l|c|c|c|c|c|c|c|}
\hline \multirow{2}{*}{\multicolumn{1}{|c|}{ Factors }} & \multicolumn{2}{|c|}{ Mean } & $\begin{array}{c}\text { Std. } \\
\text { Deviation }\end{array}$ & \multicolumn{2}{c|}{ Skewness } & \multicolumn{2}{c|}{ Kurtosis } \\
\cline { 2 - 8 } & Statistic & $\begin{array}{c}\text { Std. } \\
\text { Error }\end{array}$ & Statistic & Statistic & $\begin{array}{c}\text { Std. } \\
\text { Error }\end{array}$ & Statistic & $\begin{array}{c}\text { Std. } \\
\text { Error }\end{array}$ \\
\hline Organizational Performance & 3.7814 & 0.0386 & 1.08967 & -0.886 & 0.087 & 0.224 & 0.173 \\
\hline Ethical Dimension & 3.7601 & 0.0385 & 1.08805 & -0.817 & 0.087 & 0.138 & 0.173 \\
\hline Philanthropic Dimension & 3.9171 & 0.0394 & 1.11396 & -0.942 & 0.087 & 0.275 & 0.173 \\
\hline Sustainable Dimension & 3.9083 & 0.0393 & 1.10931 & -0.938 & 0.087 & 0.292 & 0.173 \\
\hline Brand Image & 3.8455 & 0.0383 & 1.08274 & -0.924 & 0.087 & 0.410 & 0.173 \\
\hline Brand Awareness & 3.9271 & 0.0396 & 1.11917 & -0.946 & 0.087 & 0.257 & 0.173 \\
\hline Corporate Image & 3.8455 & 0.0380 & 1.07340 & -0.925 & 0.087 & 0.451 & 0.173 \\
\hline
\end{tabular}

\subsection{Reliabilities and validities analyses}

We have employed a rotated component matrix to extract factor loading of constructs and items, and then measured average variance extracted and composite reliabilities by using factors loadings. The findings of Table 3 exhibits the readings of composite reliabilities \& Cronbach alphas are higher than 0.60 , and values of factors loading are ranging between 0.85-0.95, which satisfy the condition of discriminant validity (Ahmed et al., 2019; Huang et al., 2004). Moreover, the analyses of the average variance extracted showed, readings of 
all AVE are greater than 0.05. Consequently, convergent validities' conditions also satisfy, which is essential for employing an SEM-based multivariate approach (Ahmed et al., 2019; Fornell \& Larcker, 1981).

Table 3. Validities and reliabilities

\begin{tabular}{|c|c|c|c|c|c|}
\hline Factors & Items & FL & $\mathrm{CA}$ & CR & AVE \\
\hline \multirow{3}{*}{ Organizational Performance } & OP1 & 0.937 & \multirow{3}{*}{0.923} & \multirow{3}{*}{0.966} & \multirow{3}{*}{0.904} \\
\hline & OP2 & 0.979 & & & \\
\hline & OP3 & 0.937 & & & \\
\hline \multirow{3}{*}{ Ethical dimension } & ED1 & 0.930 & \multirow{3}{*}{0.866} & \multirow{3}{*}{0.949} & \multirow{3}{*}{0.862} \\
\hline & ED2 & 0.907 & & & \\
\hline & ED3 & 0.949 & & & \\
\hline \multirow{3}{*}{ Philanthropic dimension } & PD1 & 0.929 & \multirow{3}{*}{0.904} & \multirow{3}{*}{0.948} & \multirow{3}{*}{0.859} \\
\hline & PD2 & 0.905 & & & \\
\hline & PD3 & 0.946 & & & \\
\hline \multirow{3}{*}{ Sustainable dimension } & SD1 & 0.931 & \multirow{3}{*}{0.925} & \multirow{3}{*}{0.945} & \multirow{3}{*}{0.852} \\
\hline & SD2 & 0.904 & & & \\
\hline & SD3 & 0.935 & & & \\
\hline \multirow{3}{*}{ Brand Image } & BI1 & 0.933 & \multirow{3}{*}{0.883} & \multirow{3}{*}{0.946} & \multirow{3}{*}{0.853} \\
\hline & $\mathrm{BI} 2$ & 0.904 & & & \\
\hline & $\mathrm{BI} 3$ & 0.933 & & & \\
\hline \multirow{3}{*}{ Brand Awareness } & BA1 & 0.932 & & & \\
\hline & BA2 & 0.906 & 0.901 & 0.947 & 0.857 \\
\hline & BA3 & 0.940 & & & \\
\hline \multirow{3}{*}{ Corporate Image } & CI1 & 0.929 & \multirow{3}{*}{0.911} & \multirow{3}{*}{0.948} & \multirow{3}{*}{0.858} \\
\hline & $\mathrm{CI} 2$ & 0.909 & & & \\
\hline & CI3 & 0.941 & & & \\
\hline
\end{tabular}

Note: FL - Factor Loading; CA - Cronbach's Alpha; CR - Composite Reliability; AVE - Average Variance Extracted; CI - Corporate image; ED - Ethical dimension; PD - Philanthropic dimension; SD Sustainable dimension; OP - Organizational Performance; BI - Brand image; BA - Brand Awareness; CI - Corporate image.

\subsection{Exploratory Factor Analysis - EFA}

According to Emory and Cooper (1991), the EFA is the suitable approach to retain and validate the constructs and items. The findings of Table 4 demonstrated that the readings of factor loadings of constructs and items through the rotated component matrix that substantiated both convergent and discriminant validities. Therefore, we have retained all the items and constructs for our hypothesized measurement model (Ahmed et al., 2020). For our hypothesized measured model, we have taken three items of organizational performance. For CSR dimensions such as ethical, philanthropic, and sustainable, we have considered three items for each CSR initiative. Similarly, for two mediating variables (brand image \& brand awareness), we considered three items for each, and the moderator (corporate image) also taken three items. Since the values of factor loadings, each construct and item is higher than 0.60; thus, we have retained all the items and constructs (Ahmed et al., 2019; Kaiser, 1974). 
Table 4. Rotated Component Matrix ${ }^{\mathrm{a}}$

\begin{tabular}{|c|c|c|c|c|c|c|c|}
\hline \multirow[b]{2}{*}{ Items } & \multicolumn{7}{|c|}{ Component } \\
\hline & $\begin{array}{l}\text { Organizational } \\
\text { performance }\end{array}$ & $\begin{array}{c}\text { Ethical } \\
\text { dimension }\end{array}$ & $\begin{array}{c}\text { Philanthropic } \\
\text { dimension }\end{array}$ & $\begin{array}{l}\text { Sustainable } \\
\text { dimension }\end{array}$ & $\begin{array}{l}\text { Brand } \\
\text { image }\end{array}$ & $\begin{array}{c}\text { Brand } \\
\text { awareness }\end{array}$ & $\begin{array}{c}\text { Corporate } \\
\text { image }\end{array}$ \\
\hline OP1 & 0.937 & & & & & & \\
\hline OP2 & 0.879 & & & & & & \\
\hline OP3 & 0.937 & & & & & & \\
\hline ED1 & & 0.930 & & & & & \\
\hline ED2 & & 0.907 & & & & & \\
\hline ED3 & & 0.949 & & & & & \\
\hline PD1 & & & 0.929 & & & & \\
\hline PD2 & & & 0.905 & & & & \\
\hline PD3 & & & 0.946 & & & & \\
\hline SD1 & & & & 0.931 & & & \\
\hline SD2 & & & & 0.904 & & & \\
\hline SD3 & & & & 0.935 & & & \\
\hline BI1 & & & & & 0.933 & & \\
\hline BI2 & & & & & 0.904 & & \\
\hline $\mathrm{BI} 3$ & & & & & 0.933 & & \\
\hline BA1 & & & & & & 0.932 & \\
\hline BA2 & & & & & & 0.906 & \\
\hline BA3 & & & & & & 0.940 & \\
\hline $\mathrm{CI} 1$ & & & & & & & 0.929 \\
\hline $\mathrm{CI} 2$ & & & & & & & 0.909 \\
\hline $\mathrm{CI} 3$ & & & & & & & 0.941 \\
\hline
\end{tabular}

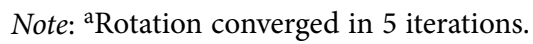

\subsection{Kaiser-Meyer-Olkin (KMO) and Bartlett's analyses}

According to Kaiser (1974), the reading of KMO analysis is 0.721 , which exhibits a good because values range between $0.70-0.79$, are known to be fair, and readings between 0.80 0.99 are considered to be excellent. Similarly, the p-value of Bartlett's analysis exhibits 0.000 , which is $\mathrm{p}<0.05$. Hence, according to Kaiser (1974), it is confirmed that at a $5 \%$ level of significance, the correlation between constructs and items is cogent and satisfactory; the detailed results are reported in Table 5.

Table 5. KMO and Bartlett's Test

\begin{tabular}{|l|c|c|}
\hline \multicolumn{2}{|c|}{ Kaiser-Meyer-Olkin Measure of Sampling Adequacy } & 0.721 \\
\hline \multirow{3}{*}{ Bartlett's Test of Sphericity } & Approx. Chi-Square & 12657.988 \\
\cline { 2 - 3 } & Df & 210 \\
\cline { 2 - 3 } & Sig. & 0.000 \\
\hline
\end{tabular}




\subsection{Total variance explained}

According to Ahmed et al. (2020), the cumulative percentage of seven constructs variance exhibits the dispersal of potential factors' variance. The outcomes of Table 6 suggested that the aggregate percentage of variance is 85.902 (80.90\%), which seems to be an excellent (Kaiser, 1974) because the cut-off value is $50 \%$. Moreover, the readings of each construct's total Eigenvalues are higher than one; thus, it shows our considered variables area suitable and gathered data is trustworthy.

Table 6. Total variance explained

\begin{tabular}{|c|c|c|c|c|c|c|c|c|c|}
\hline \multirow{2}{*}{$\begin{array}{l}\text { चี } \\
\text { : } \\
\text { : } \\
\text { : }\end{array}$} & \multicolumn{3}{|c|}{ Initial Eigenvalues } & \multicolumn{3}{|c|}{$\begin{array}{l}\text { Extraction Sums of Squared } \\
\text { Loadings }\end{array}$} & \multicolumn{3}{|c|}{$\begin{array}{c}\text { Rotation Sums of Squared } \\
\text { Loadings }\end{array}$} \\
\hline & Total & $\begin{array}{c}\% \text { of } \\
\text { Variance }\end{array}$ & $\begin{array}{c}\text { Cumulative } \\
\%\end{array}$ & Total & $\begin{array}{c}\% \text { of } \\
\text { Variance }\end{array}$ & $\begin{array}{c}\text { Cumulative } \\
\%\end{array}$ & Total & $\begin{array}{c}\% \text { of } \\
\text { Variance }\end{array}$ & $\begin{array}{c}\text { Cumulative } \\
\%\end{array}$ \\
\hline 1 & 2.950 & 14.048 & 14.048 & 2.950 & 14.048 & 14.048 & 2.599 & 12.374 & 12.374 \\
\hline 2 & 2.814 & 13.400 & 27.447 & 2.814 & 13.400 & 27.447 & 2.587 & 12.320 & 24.693 \\
\hline 3 & 2.692 & 12.820 & 40.267 & 2.692 & 12.820 & 40.267 & 2.585 & 12.311 & 37.004 \\
\hline 4 & 2.527 & 12.034 & 52.301 & 2.527 & 12.034 & 52.301 & 2.584 & 12.306 & 49.311 \\
\hline 5 & 2.462 & 11.723 & 64.025 & 2.462 & 11.723 & 64.025 & 2.579 & 12.279 & 61.590 \\
\hline 6 & 2.371 & 11.292 & 75.316 & 2.371 & 11.292 & 75.316 & 2.567 & 12.223 & 73.813 \\
\hline 7 & 2.223 & 10.586 & 85.902 & 2.223 & 10.586 & 85.902 & 2.539 & 12.090 & 85.902 \\
\hline
\end{tabular}

Note: Extraction method: Principal component analysis.

\subsection{Confirmatory factor analysis}

For the securitizing the measurement model, we have employed a direct approach such as confirmatory factor analysis (CFA). According to Hair et al. (2010), CFA is a suitable technique to establish the robustness of sample data for the considered hypothesized measured model. In our hypothesized measured model, we considered organizational performance as a dependent factor with three items. The dimensions of ethical, philanthropic, and sustainable are considered as CSR initiatives with three items each. Similarly, brand awareness and brand image are considered as mediators with three items each. Finally, we have incorporated corporate image as a moderating variable with three items in our hypothesized measurement model. According to Ahmed et al. (2020) and Fornell and Larcker (1981), the data should be fixed into observed and unobserved variables for the hypothesized measurement model. The considered hypothesized measured model has twenty-one items; the values of factor loadings are ranging between 0.85-0.95, hence, according to Hair et al. (2010), and Ahmed et al. (2019), the considered measurement model is acceptable. The outcomes of fitindices exhibit that all the readings are within the threshold range for instance RNI $=0.96$, $\mathrm{IFI}=0.96, \mathrm{GFI}=0.96, \mathrm{NFI}=0.94$, TLI $=0.99, \mathrm{CFI}=0.96, \mathrm{PNFI}=0.85, \mathrm{PCFI}=0.83$, and RMSEA $=0.027$. Hence, it is confirmed the considered hypothesized measured model is suitable for the organizational performance. 


\subsection{Structural equation modeling}

We have employed structural equation modeling to estimate parameters of organizational performance; the considered hypothesized structural model has organizational performance as a dependent variable. The considered structural model employed three independent factors: CSR initiatives such as ethical, philanthropic, and sustainable dimensions, brand awareness and brand image as mediating, and corporate image as a moderator. We employed seven factors with twenty-one items, the outcomes of fit-indices exhibit that all the readings are within the threshold range, for instance, $\mathrm{RNI}=0.97$, IFI $=0.97, \mathrm{NFI}=0.95, \mathrm{GFI}=0.98$, $\mathrm{TLI}=0.98, \mathrm{CFI}=0.97, \mathrm{RMSEA}=0.026, \mathrm{PCFI}=0.85, \mathrm{PNFI}=0.86$. Hence, it is confirmed the considered hypothesized structural model is suitable for the organizational performance in perspective of services and manufacturing sectors of China, India, Pakistan, and Bangladesh.

\subsection{Hypothesized direct relationship}

The results of Table 7 demonstrated the hypothesized direct relationship between independent variables such as ethical, philanthropic, and sustainable dimensions, and organizational performance. The standardized regression weights showed that the ethical dimension has a compelling and affirmative impact on organizational performance because $\mathrm{p}<0.05 \& \mathrm{~T}>2$ with $\beta=0.1228$ that is the lowest impact compared to other dimensions. The conclusion of the second dimension, such as philanthropic, further determined an affirmative and cogent effect on organizational performance with $\beta=0.2838$. However, the sustainable dimension has demonstrated the most significant and positive impact on organizational performance with $\beta=0.3107$. Hence, it is finally established that hypotheses $\mathrm{H} 1, \mathrm{H} 2$, and $\mathrm{H} 3$ are supported due to $\mathrm{p}<0.05 \& \mathrm{~T}>2$, and ethical, philanthropic, and sustainable dimensions have an affirmative and influential impact on organizational performance.

Table 7. Hypothesized direct relationship

\begin{tabular}{|c|l|c|c|c|c|c|c|}
\hline Hyp. & Variables & $\begin{array}{c}\text { Regression } \\
\text { Paths }\end{array}$ & $\begin{array}{c}\text { Standardized } \\
\text { Regression weights }\end{array}$ & SE & $\mathrm{T}$ & $\mathrm{P}^{*}$ & Decision \\
\hline H1 & $\begin{array}{l}\text { Ethical } \\
\text { dimension }\end{array}$ & $\mathrm{ED} \rightarrow \mathrm{OP}$ & 0.1228 & 0.027 & 4.58 & 0.000 & Supported \\
\hline H2 & $\begin{array}{l}\text { Philanthropic } \\
\text { dimension }\end{array}$ & $\mathrm{PD} \rightarrow \mathrm{OP}$ & 0.2838 & 0.035 & 8.21 & 0.000 & Supported \\
\hline H6 & $\begin{array}{l}\text { Sustainable } \\
\text { dimension }\end{array}$ & $\mathrm{SD} \rightarrow \mathrm{OP}$ & 0.3107 & 0.036 & 8.56 & 0.000 & Supported \\
\hline
\end{tabular}

Note: ${ }^{*} \mathrm{p}<0.05$ (rejected at $5 \%$ level of significance).

\subsection{Mediation analysis}

We incorporated two mediating variables in our modified conceptual model, such as brand image and brand awareness. We examine mediation's influence in an association between ethical, philanthropic, and sustainable dimensions, and organizational performance. We used two methods to measure the mediating effect; first, we employed the Bootstrapping method (Hayes \& Rockwood, 2020) in which we inferred the zero does not lie between BootLLCI and Boot ULCI. Thus it is established that there is perfect mediation of brand image and brand 
awareness between ethical, philanthropic, and sustainable dimensions and organizational performance. The findings of Table 8 further exhibited the Normal theory method (Sobel, 1986) in which we concluded that $\mathrm{p}<0.05 \& \mathrm{Z}>1.96$ in all the cases. Thus, it is again established that brand image and brand awareness significantly affect a relationship between exogenous and endogenous variables. Now, it is finally concluded that hypotheses H4A, H4B, $\mathrm{H} 4 \mathrm{C}, 5 \mathrm{HA}, 5 \mathrm{HB}$, and $5 \mathrm{HC}$ are supported, and brand image $\&$ brand awareness have a perfect mediation between ethical, philanthropic, and sustainable dimensions and organizational performance in perspective of services and manufacturing sectors of South Asian economies.

Table 8. Mediation analysis

\begin{tabular}{|c|c|c|c|c|c|c|c|c|c|c|}
\hline \multirow{2}{*}{ 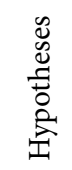 } & \multirow[b]{2}{*}{ Mediation } & \multicolumn{4}{|c|}{ Bootstrapping Method } & \multicolumn{4}{|c|}{ Normal Theory Method } & \multirow[b]{2}{*}{ Decision } \\
\hline & & $\begin{array}{l}\text { Indirect } \\
\text { Effect }\end{array}$ & $\begin{array}{c}\text { Boot } \\
\text { SE }\end{array}$ & $\begin{array}{l}\text { Boot } \\
\text { LLCI }\end{array}$ & $\begin{array}{l}\text { Boot } \\
\text { ULCI }\end{array}$ & $\begin{array}{l}\text { Indirect } \\
\text { Effect }\end{array}$ & S.E. & $\mathrm{Z}^{*}$ & $\underset{* *}{\text { Prob. }}$ & \\
\hline H4A: & $\mathrm{ED} \rightarrow \mathrm{BI} \rightarrow \mathrm{OP}$ & 0.141 & 0.030 & 0.081 & 0.199 & 0.141 & 0.021 & 6.69 & 0.000 & Supported \\
\hline H4B: & $\mathrm{PD} \rightarrow \mathrm{BI} \rightarrow \mathrm{OP}$ & 0.107 & 0.015 & 0.075 & 0.137 & 0.107 & 0.018 & 5.69 & 0.000 & Supported \\
\hline H4C: & $\mathrm{SD} \rightarrow \mathrm{BI} \rightarrow \mathrm{OP}$ & 0.120 & 0.016 & 0.088 & 0.821 & 0.120 & 0.017 & 7.05 & 0.000 & Supported \\
\hline H5A: & $\mathrm{ED} \rightarrow \mathrm{BA} \rightarrow \mathrm{OP}$ & 0.543 & 0.023 & 0.497 & 0.589 & 0.543 & 0.022 & 23.94 & 0.000 & Supported \\
\hline H5B: & $\mathrm{PD} \rightarrow \mathrm{BA} \rightarrow \mathrm{OP}$ & 0.490 & 0.032 & 0.428 & 0.555 & 0.490 & 0.026 & 18.37 & 0.000 & Supported \\
\hline H5F: & $\mathrm{SD} \rightarrow \mathrm{BA} \rightarrow \mathrm{OP}$ & 0.463 & 0.036 & 0.391 & 0.535 & 0.463 & 0.030 & 15.41 & 0.000 & Supported \\
\hline
\end{tabular}

Note: ${ }^{*}$ Denotes the values of $\mathrm{Z}>1.96$ and $\mathrm{Z}>-1.96$; ${ }^{* *}$ denotes $\mathrm{p}<0.05$.

\subsection{Moderation analysis}

We incorporated one moderating variable in our modified conceptual model such as corporate image; we examine moderation's influence in an association between ethical, philanthropic, and sustainable dimensions, and organizational performance. The findings of Table 9 exhibited the values of $\mathrm{p}<0.05$ and $\mathrm{T}>2$. Thus, hypotheses H6A, H6B, and H6C

Table 9. Moderating effect

\begin{tabular}{|c|c|c|c|c|c|c|c|c|c|}
\hline Hypotheses & Moderator & Moderation & Coefficient & SE & $\mathrm{T}$ & $\mathrm{P}^{*}$ & LLCI & ULCI \\
\hline \multicolumn{7}{|c|}{ Moderation of Corporate Image between Ethical dimension \& Organizational performance } \\
\hline H6A: & $\begin{array}{c}\text { Corporate } \\
\text { image }\end{array}$ & ED x CI & -0.210 & 0.014 & -14.83 & 0.000 & -0.238 & -0.183 \\
\hline Moderation of Corporate Image between Philanthropic dimension \& Organizational performance \\
\hline H6B: & $\begin{array}{c}\text { Corporate } \\
\text { image }\end{array}$ & PD x CI & -0.060 & 0.013 & -4.61 & 0.000 & -0.086 & -0.034 \\
\hline Moderation of Corporate Image between Sustainable dimension \& Organizational performance \\
\hline H6C: & $\begin{array}{c}\text { Corporate } \\
\text { image }\end{array}$ & SD x CI & -0.053 & 0.012 & -4.29 & 0.000 & -0.077 & -0.028 \\
\hline
\end{tabular}

Note: Moderator - CI - Corporate image; ED - Ethical dimension; PD - Philanthropic dimension; $\mathrm{SD}$ - Sustainable dimension; ${ }^{\star}$ Signifies rejection of Hypotheses at $95 \%$ confidence interval $(\mathrm{p}<0.05)$; " $\mathrm{x}$ " is known as the multiplicative sign. 
are supported. Hence, it is finally concluded that corporate image has a significant moderating impact between ethical, philanthropic, and sustainable dimensions, and organizational performance in perspective of services and manufacturing sectors of China, India, Pakistan, and Bangladesh.

\subsection{Virtualization of conditional effect}

The findings of visualizing influence of moderating variable such as corporate image depicted in Figure 2 to Figure 4 that demonstrated a significant impact of moderation between ethical, philanthropic, and sustainable dimensions, and organizational performance. The pictorial

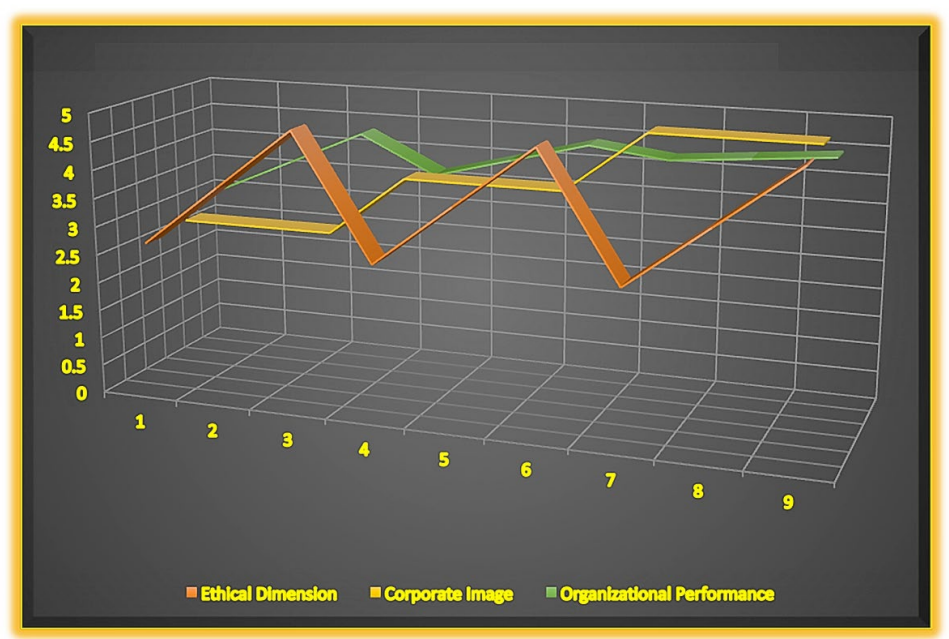

Figure 2. Graphical depiction of moderation (corporate image) between ethical dimension \& organizational performance

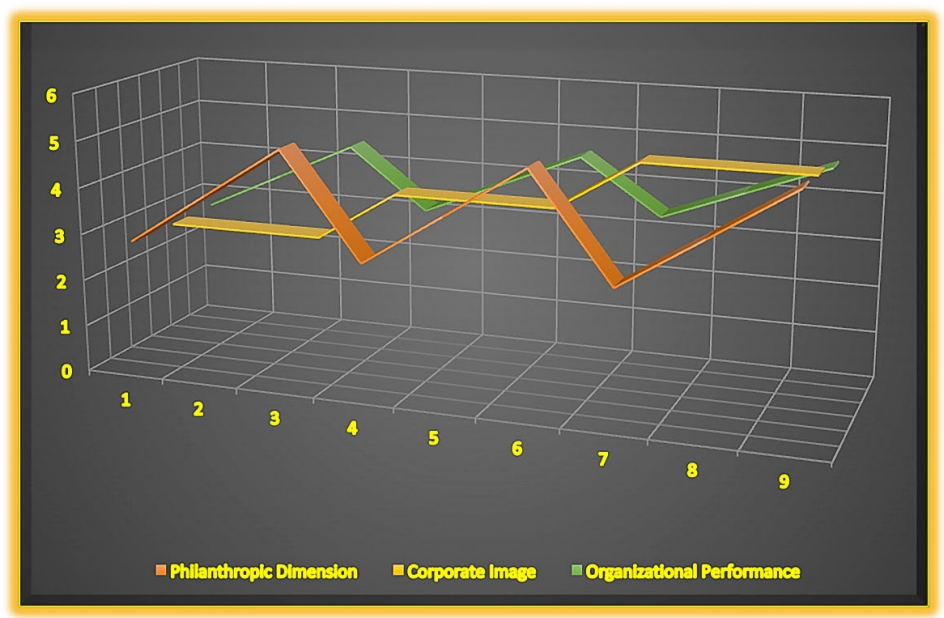

Figure 3. Graphical depiction of moderation (corporate image) between philanthropic dimension \& organizational performance 


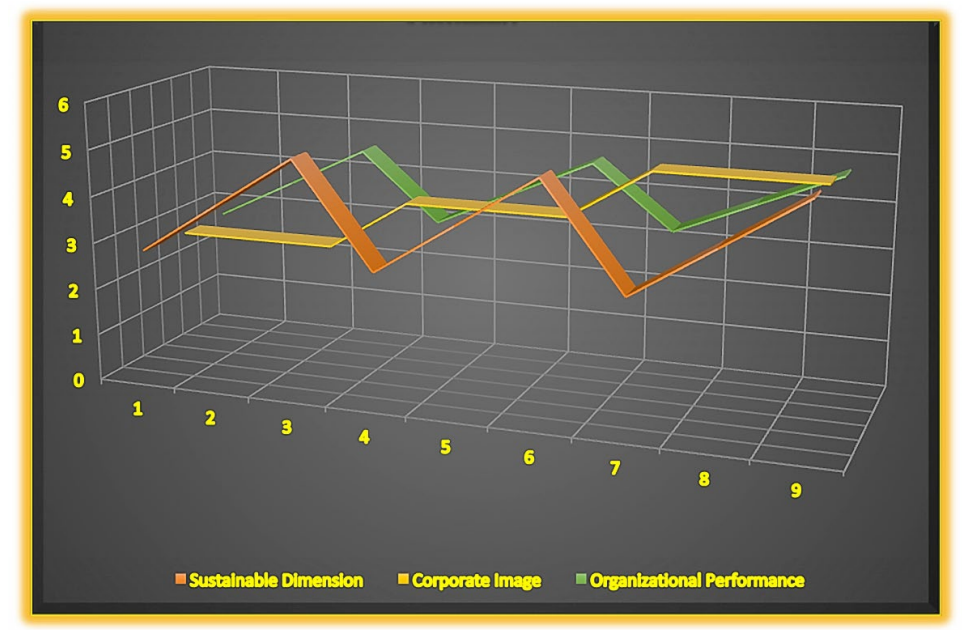

Figure 4. Graphical depiction of moderation (corporate image) between sustainable dimension \& organizational performance

representation is an essential and fundamental condition for moderation between exogenous and endogenous variables (Hayes \& Rockwood, 2020). The findings from Figure 2 to Figure 4 exhibited that the organizational performance readings are changing with the variation of corporate image (moderating variable). However, exogenous variables were kept constant. The green color showed for the organizational performance, the yellow color exhibited for the moderation, and orange color depicted for the ethical, philanthropic, and sustainable dimensions (exogenous variables). Thus, it is conclusively proven that corporate image significantly influences between ethical, philanthropic, and sustainable dimensions and organizational performance.

\section{Discussions}

The undertaken study's findings revealed that ethical and philanthropic dimensions have an affirmative and cogent impact on organizational performance. Thus, this demonstrated that companies are sensitive to societal obligations and conserved CSR as a unique business strategy that enhances competitive advantage and long-term growth. The preceding studies also suggested the same outcomes in which ethical and philanthropic dimensions are considered to be a vital CSR initiative that ultimately enhances firm's performance (Park, 2019; Lu et al., 2020b; Gardberg et al., 2019; Hwang \& Lyu, 2018; Flammer \& Luo, 2017). The results of this research further revealed that the sustainable dimension (TBL approach) has a compelling and positive effect on organizational performance. The sustainability in business strategies, environmental obligations, corporate strategies, and tactical strategies are paramount to achieve sustainable long-term growth in today's competitive environment. The outcomes of previous literature also demonstrated the same results (Zulfiqar et al., 2019; Lu et al., 2020b; Jeon \& An, 2019; Slapper \& Hall, 2011; Ottman, 2011; Kuo et al., 2016; Coles et al., 2013). The mediation results revealed a cogent impact of brand image amid ethical, philanthropic, 
and sustainable dimensions and organizational performance. Hence, it is confirmed that CSR initiatives substantiated companies' brand image, which further enhances organizational performance and provides a long-term competitive advantage. Previous literature also confirmed these results in which CSR initiatives enhance the brand image, and due to the value addition of brands, the overall organizational performances also increased (Yang \& Basile, 2019; Dawood, 2019; Ahmed et al., 2017; Martínez et al., 2014; Du, Bhattacharya \& Sen, 2010; Werther \& Chandler, 2005; Wu \& Wang, 2014; Keller, 1993; Grönroos, 2007). Similarly, the undertaken research outcomes further exhibited that brand awareness is a significant and positive mediating variable between ethical, philanthropic, and sustainable dimensions and organizational performance. Previous literature's findings determined the similar outcomes such as Rahman et al. (2019), Ahmed et al. (2017), Melewar and Karaosmanoglu (2006), Balmer and Greyser (2006), Nan and Kwangjun (2007), and Wu and Wang (2014). Finally, a moderator's corporate image has a cogent influence between ethical, philanthropic, and sustainable dimensions and organizational performance. The outcomes of preceding literature also demonstrated that CSR initiatives enhance the company's goodwill and images such as Lu et al. (2020b), Moliner et al. (2019), Suki and Suki (2019), Richard and Zhang (2012), Ahn et al. (2020), Singh and Saini (2016), and Han et al. (2019).

\section{Conclusions}

The undertaken study's outcomes substantiated the modified theoretical framework in which ethical and philanthropic dimensions concluded a cogent and affirmative effect on a firm's performance and sustainable growth. Therefore, firms' should stretch more prominence to the ethical and philanthropic dimensions while formulating organizational strategies. Likewise, the sustainable dimension (Triple bottom line approach) also concluded a cogent and positive influence on organizational performance. The undertaken research outcomes confirmed that brand image and brand awareness are the right business strategies because they have an affirmative and significant association between ethical, philanthropic, and sustainable dimensions and organizational performance. Conclusively, it has also confirmed that corporate image is a significant moderating variable amid independent variables and a firm's performance. It is determined in this study that the services and manufacturing sectors of China, India, Pakistan, and Bangladesh could formulate better business strategies to increase the organizational performance \& competitiveness, corporate image, and employees' efficiency. Moreover, cause-related marketing also enhances the competitive advantage and firm's performance. To achieve industry success, the firm has to provide social and transient benefits to the customers, employees, community, and shareholders. This research concluded that the firm has to rollout effective CSR initiatives by adding a sustainable dimension as a business strategy that also increases corporate image and sustainable long-term growth. The undertaken research may add value by incorporating CSR initiatives as ethical, philanthropic, and sustainable dimensions as a business strategy, which should be integrated into the CSR initiatives to address social and environmental concerns. Finally, the undertaken research established that the corporate image is a cogent moderating factor that increases long-term 
sustainable growth, and brand image \& brand awareness are significant mediators, which also increase organizational performance. The undertaken research endorses that brand image, brand awareness, and brand image in terms of employees, community, suppliers, shareholders, and customers are important factors that should be further explored in future studies. The findings of this research concluded that the corporate social responsibility practices are the most effective and persuasive business strategy that increases completive performance and long-term sustainable growth of an organization. The CSR strategy not only enhances the corporate image but also has a significant positive impact on companies' brands in terms of image, awareness, and brand equity in a long-term. The CSR practices intact the employees, customers, and community with the brands that also provides long-term sustainable growth and competitive advantage.

\section{Theoretical and practical implications}

The findings of this research added a new knowledge in the CSR relevant marketing strategies, and proposed a novel model that will be useful for the future research studies. The derived model can be implemented in specific industries, and developed and developing economies to confirm the CSR as a business strategy. The outcomes of the undertaken research established that the CSR initiatives are the most effective and potent business strategy that increases organizational performance and competitive advantage. Therefore, the organization's managers must integrate CSR initiatives as an effective business strategy to boost the employees' morale. This study analyzed that the corporate image has a direct link to CSR; thus, managers should create a company's brand CSR image in the customers' minds. Comparing with previous studies that only focused on CSR programs aiming to increase consumer satisfaction. This study demonstrated a new horizon of incorporating brand image, brand awareness, corporate image, CSR initiatives such as philanthropic, ethical, and sustainable dimensions to formulae business strategies that enhance sustainable growth and long-term organizational performance through competitive advantage.

\section{Limitations and potential areas of future research studies}

This research study has certain limitations such as the undertaken study is cross-sectional that addresses the current period; however, the technology is changing rapidly. Thus, it is recommended to the future researchers that they may replicate this study over a longitudinal design. We have used only four developing economies; therefore, it is recommended that future studies may be carried out with more developing economies from different regions of the world for more robust results, which can be generalizable for the entire world. Nonetheless, this research and its findings provide the foundation for future research studies that could be carried out for other emerging countries. Furthermore, these conclusions may be generalized to different contexts and should be interpreted. Furthermore, the cause and effect models can produce better understandings of variables association. Thus, future researchers can employ more robust models that demonstrate the cause and effect amongst the variables. 


\section{References}

Abid, T., Abid-Dupont, M. A., \& Moulins, J. L. (2020). What corporate social responsibility brings to brand management? The two pathways from social responsibility to brand commitment. Corporate Social Responsibility and Environmental Management, 27(2), 925-936. https://doi.org/10.1002/csr.1856

Aguinis, H., \& Glavas, A. (2013). Embedded versus peripheral corporate social responsibility: Psychological foundations. Industrial and Organizational Psychology, 6(4), 314-332. https://doi.org/10.1111/iops.12059

Ahmed, R. R., Hussain, S., Pahi, M. H., Usas, A., \& Jasinskas, E. (2019). Social media handling and Extended Technology Acceptance Model (ETAM): Evidence from SEM-based multivariate approach. Transformations in Business \& Economics, 18(3), 246-271.

Ahmed, R. R., Štreimikienè, D., Abrhám, J., Streimikis, J., \& Vveinhardt, J. (2020). Social \& behavioural theories and physicians' prescription behaviour. Sustainability, 12(8), 3379. https://doi.org/10.3390/su12083379

Ahmed, R. R., Vveinhardt, J., \& Štreimikienè, D. (2017). Interactive digital media and impact of customer attitude and technology on brand awareness: Evidence from the South Asian countries. Journal of Business Economics and Management, 18(6), 1115-1134. http://dx.doi.org/10.3846/16111699.2017.1400460

Ahn, J., Wong, M. L., \& Kwon, J. (2020). Different role of hotel CSR activities in the formation of customers' brand loyalty. International Journal of Quality and Service Sciences, 12(3), 337-353. https://doi.org/10.1108/IJQSS-02-2020-0028

Almeida, M. G. M. C., \& Coelho, A. F. M. (2019). The antecedents of corporate reputation and image and their impacts on employee commitment and performance: The moderating role of CSR. Corporate Reputation Review, 22(1), 10-25. https://doi.org/10.1057/s41299-018-0053-8

Alrubaiee, L., Aladwan, S., Hussein, M., Idris, W. M., \& Khater, S. (2017). Relationship between corporate social responsibility and marketing performance: The mediating effect of customer value and corporate image. International Business Research, 10(2), 104-123. https://doi.org/10.5539/ibr.v10n2p104

Balmer, J. M. T., \& Greyser, S. A. (2006). Corporate marketing: Integrating corporate identity, corporate branding, corporate communications, corporate image and corporate reputation. European Journal of Marketing, 40(7/8), 730-741. https://doi.org/10.1108/03090560610669964

Baumgartner, R. J. (2014). Managing corporate sustainability and CSR: A conceptual framework combining values, strategies and instruments contributing to sustainable development. Corporate Social Responsibility and Environmental Management, 21(5), 258-271. https://doi.org/10.1002/csr.1336

Bhattacharya, C. B., \& Sen, S. (2004). Doing better at doing good: When, why, and how consumers respond to corporate social initiatives. California Management Review, 47(1), 9-24. https://doi.org/10.2307/41166284

Boonpattarakan, A. (2012). An experimental design to test the main and interaction effects of CSR involvement, brand naming and pricing on purchase intentions in Thailand. International Journal of Business and Management, 7(16), 62-79. https://doi.org/10.5539/ijbm.v7n16p62

Bowen, H. R. (1953). Social responsibilities of the businessman. Harper.

Bronn, P. S., \& Vrioni, A. B. (2011). Corporate social responsibility and cause-related marketing: An overview. International Journal of Advertising, 20, 207-222.

Byrne, B. M. (2009). Structural equation modeling with AMOS, basic concepts, application and programming ( $2^{\text {nd }}$ ed.). Hillsdale.

Calabrese, A., \& Lancioni, F. (2008). Analysis of corporate social responsibility in the service sector: Does exist a strategic path? Knowledge and Process Management, 15(2), 107-125.

https://doi.org/10.1002/kpm.303 
Carroll, A. B. (1979). A three-dimensional conceptual model of corporate performance. Academy of Management Review, 4(4), 497-505. https://doi.org/10.5465/amr.1979.4498296

Carroll, A. B. (1991). The pyramid of corporate social responsibility: Toward the moral management of organizational stakeholders. Business Horizons, 34(4), 39-48.

https://doi.org/10.1016/0007-6813(91)90005-G

Carroll, A. B. (2004). Managing ethically with global stakeholders: A present and future challenge. Academy of Management Perspective, 18(2), 114-120. https://doi.org/10.5465/ame.2004.13836269

Carroll, A. B. (2008). A history of corporate social responsibility: Concepts and practices. In The Oxford handbook of corporate social responsibility (pp. 19-46). Oxford University Press. https://doi.org/10.1093/oxfordhb/9780199211593.003.0002

Carroll, A. B. (2016). Carroll's Pyramid of CSR: Taking another look. International Journal of Corporate Social Responsibility, 1(3), 1-8. https://doi.org/10.1186/s40991-016-0004-6

Casado-Díaz, A. B., Nicolau-Gonzálbez, J. L., Ruiz-Moreno, F., \& Sellers-Rubio, R. (2014). The differentiated effects of CSR actions in the service industry. Journal of Services Marketing, 28(7), 558-565. https://doi.org/10.1108/JSM-07-2013-0205

Chang, D. S., Chen, S. H., Hsu, C. W., \& Hu, A. H. (2015). Identifying strategic factors of the implantation CSR in the airline industry: The case of Asia-Pacific airlines. Sustainability, 7(6), 7762-7783. https://doi.org/10.3390/su7067762

Chen, C. J., Guo, R. S., Hsiao, Y. C., \& Chen, K. L. (2018). How business strategy in non-financial firms moderates the curvilinear effects of corporate social responsibility and irresponsibility on corporate financial performance. Journal of Business Research, 92, 154-167. https://doi.org/10.1016/j.jbusres.2018.07.030

Chen, J., Liu, J., \& Qin, J. (2019). Corporate social responsibility and capacity selection. Transformations in Business \& Economics, 18(3C(48C)), 530-545.

Cho, S. J., Song, H. J., Lee, C. K., \& Lee, S. K. (2017). The impact of CSR on airline passengers' corporate image, customer trust, and behavioral intentions: An empirical analysis of safety activity. Hotel Management Studies, 26(4), 87-106. https://doi.org/10.24992/KJHT.2017.06.26.04.87.

Coles, T., Fenclova, E., \& Dinan, C. (2013). Tourism and corporate social responsibility: A critical review and research agenda. Tourism Management Perspectives, 6, 122-141.

https://doi.org/10.1016/j.tmp.2013.02.001

Comrey, A. L., \& Lee, H. B. (1992). A first course in factor analysis. London: Routledge.

Cretu, A. E., \& Brodie, R. J. (2007). The influence of brand image and company reputation where manufacturers market to small firms: A customer value perspective. Industrial Marketing Management, 36(2), 230-240. https://doi.org/10.1016/j.indmarman.2005.08.013

Dawood, H. (2019). Influence of perceived corporate social responsibility on brand image, satisfaction and trust. Lahore Journal of Business, 7(2), 33-58. https://doi.org/10.35536/ljb.2019.v7.i2.a2

Demirel, A. (2020). CSR in sport sponsorship consumers' perceptions of a sponsoring brand's CSR. International Journal of Sports Marketing and Sponsorship, 21(2), 371-388. https://doi.org/10.1108/IJSMS-09-2019-0108

Domi, S., Keco, R., Capelleras, J. L., \& Mehmeti, G. (2019). Effects of innovativeness and innovation behavior on tourism SMEs performance: The case of Albania. Economics and Sociology, 12(3), 67-85. https://doi.org/10.14254/2071-789X.2019/12-3/5

Du, S., Bhattacharya, C. B., \& Sen, S. (2010). Maximizing business returns to Corporate Social Responsibility (CSR): The role of CSR communication. International Journal of Management Reviews, 12(1), 8-19. https://doi.org/10.1111/j.1468-2370.2009.00276.x

Dyck, A., Lins, K. V., Roth, L., \& Wagner, H. F. (2019). Do institutional investors drive Corporate Social Responsibility? International evidence. Journal of Financial Economics, 131(3), 693-714. https://doi.org/10.1016/j.jfineco.2018.08.013 
Elkington, J. (1999). Cannibals with forks: The triple bottom line of $21^{\text {st }}$ century business. John Wiley \& Son Ltd.

Emory, C. W., \& Cooper, D. R. (1991). Business research methods ( $4^{\text {th }}$ ed.). Richard D Irwin.

Farid, T., Iqbal, S., Ma, J., Castro, G. S., Khattak, A., \& Khan, M. K. (2019). Employees' perceptions of CSR, work engagement, and organizational citizenship behavior: The mediating effects of organizational justice. International Journal of Environmental Research and Public Health, 16(10), 1731. https://doi.org/10.3390/ijerph16101731

Flammer, C., \& Luo, J. (2017). Corporate social responsibility as an employee governance tool: Evidence from a quasi-experiment. Strategic Management Journal, 38(2), 163-183. https://doi.org/10.1002/smj.2492

Fornell, C., \& Larcker, D. F. (1981). Evaluating structural equation models with unobservable variables and measurement error. Journal of Marketing Research, 18(1), 39-50. https://doi.org/10.2307/3151312

Galant, A., \& Cadez, S. (2017). Corporate Social Responsibility and financial performance relationship: A review of measurement approaches. Economic Research-Ekonomska Istraživanja, 30(1), 676-693. https://doi.org/10.1080/1331677X.2017.1313122

Galbreath, J. (2010). How does corporate social responsibility benefit firms? Evidence from Australia. European Business Review, 22(4), 411-431. https://doi.org/10.1108/09555341011056186

Gardberg, N. A., Zyglidopoulos, S. C., Symeou, P. C., \& Schepers, D. H. (2019). The impact of corporate philanthropy on reputation for corporate social performance. Business and Society, 58(6), 1177-1208. https://doi.org/10.1177/0007650317694856

Grönroos, C. (2007). Service management and marketing: Customer management in service competition ( $3^{\text {rd }}$ ed.). John Wiley \& Sons Ltd.

Hair, Jr. J. F., Black, W. C., Babin, B. J., \& Anderson, R. E. (2010). Multivariate data analysis (7th ed.). Prentice Hall.

Han, H., Yu, J., \& Kim, W. (2019). Environmental corporate social responsibility and the strategy to boost the airline's image and customer loyalty intentions. Journal of Travel \& Tourism Marketing, 36(3), 371-383. https://doi.org/10.1080/10548408.2018.1557580

Hayes, A. F., \& Rockwood, N. J. (2020). Conditional process analysis: Concepts, computation, and advances in modeling of the contingencies of mechanisms. American Behavioral Scientist, 64(1), 19-54. https://doi.org/10.1177/0002764219859633

Hoque, N., Rahman, A. R. A., Molla, R. I., Noman, A. H. M., \& Bhuiyan, M. Z. H. (2018). Is corporate social responsibility pursuing pristine business goals for sustainable development? Corporate Social Responsibility and Environmental Management, 25(6), 1130-1142. https://doi.org/10.1002/csr.1527

Huang, J. H., Lee, B. C. Y., \& Ho, S. H. (2004). Consumer attitude toward grey market goods. International Marketing Review, 21(6), 598-614. https://doi.org/10.1108/02651330410568033

Hussain, S., \& Ahmed, R. R. (2020). Smartphone buying behaviors in a framework of brand experience and brand equity. Transformations in Business \& Economics, 19(2), 220-242.

Hwang, J., \& Lyu, S. O. (2018). Understanding first-class passengers' luxury value perceptions in the US airline industry. Tourism Management Perspectives, 28, 29-40. https://doi.org/10.1016/j.tmp.2018.07.001

Jeon, M. A., \& An, D. (2019). A study on the relationship between perceived CSR motives, authenticity and company attitudes: A comparative analysis of cause promotion and cause-related marketing. Asian Journal of Sustainability and Social Responsibility, 4(1), 1-14. https://doi.org/10.1186/s41180-019-0028-4

Kaiser, H. F. (1974). An index of factorial simplicity. Psychometrika, 39(1), 31-36. https://doi.org/10.1007/BF02291575

Kang, E. Y., \& Atkinson, L. (2019). Effects of message objectivity and focus on green CSR communication: The strategy development for a hotel's green CSR message. Journal of Marketing Communications, 27(3), 229-249. https://doi.org/10.1080/13527266.2019.1640270 
Kayaman, R., \& Arasli, H. (2007). Customer based equity: Evidence from the hotel industry. Managing Service Quality, 17(1), 92-109. https://doi.org/10.1108/09604520710720692

Keller, K. L. (1993), Conceptualizing, measuring and managing customer-based brand equity. Journal of Marketing, 57(1), 1-22. https://doi.org/10.1177/002224299305700101

Kitchin, T. (2003). Corporate responsibility: A brand extension. Journal of Brand Management, 10(4-5), 312-326. https://doi.org/10.1057/palgrave.bm.2540127

Kuo, T. C., Kremer, G. E. O., Phuong, N. T., \& Hsu, C. W. (2016). Motivations and barriers for corporate social responsibility reporting: Evidence from the Airline Industry. Journal of Air Transport Management, 57, 184-195. https://doi.org/10.1016/j.jairtraman.2016.08.003

Lai, C. S., Chiu, C. J., Yang, C. F., \& Pai, D. C. (2010). The effects of corporate social responsibility on brand performance: The mediating effect of industrial brand equity and corporate reputation. Journal of Business Ethics, 95(3), 457-469. https://doi.org/10.1007/s10551-010-0433-1

Lee, Y. C. (2020). Communicating sustainable development: Effects of stakeholder-centric perceived sustainability. Corporate Social Responsibility and Environmental Management, 27(4), 1540-1551. https://doi.org/10.1002/csr.1900

Lewis, S. (2003). Reputation and corporate responsibility. Journal of Communication Management, 7(4), 356-364. https://doi.org/10.1108/13632540310807494

Lho, H., Park, J., \& Yu, J. (2019). The effects of corporate social responsibility (CSR) initiatives on brand image, brand prestige, and behavioral intention. International Journal of Tourism and Hospitality Research, 33(4), 63-74. https://doi.org/10.21298/ijthr.2019.4.33.4.63

Li, Z., Liao, G., \& Albitar, K. (2020). Does corporate environmental responsibility engagement affect firm value? The mediating role of corporate innovation. Business Strategy and the Environment, 29(3), 1045-1055. https://doi.org/10.1002/bse.2416

Longo, M., Mura, M., \& Bonoli, A. (2005). Corporate social responsibility and corporate performance: The case of Italian SMEs. Corporate Governance International Journal of Business in Society, 5(4), 28-42. https://doi.org/10.1108/14720700510616578

Lu, J., Ren, L., Qiao, J., Lin, W., \& He, Y. (2019). Female executives and corporate social responsibility performance: A dual perspective of differences in institutional environment and heterogeneity of foreign experience. Transformations in Business \& Economics, 18(2) (47), 174-196.

Lu, J., Ren, L., Zhang, C., Rong, D., Ahmed, R. R., \& Streimikis, J. (2020a). Modified Carroll's Pyramid of corporate social responsibility to enhance organizational performance of SMEs industry. Journal of Cleaner Production, 271, 1-18. https://doi.org/10.1016/j.jclepro.2020.122456

Lu, J., Ren, L., Zhang, C., Wang, C., Ahmed, R. R., \& Streimikis, J. (2020b). Corporate social responsibility and employees' behavior: Evidence from mediation and moderation analysis. Corporate Social Responsibility and Environmental Management, 27(4), 1719-1728. https://doi.org/10.1002/csr.1919

MacCallum, R. C., Widaman, K., Zhang, S., \& Hong, S. (1999). Sample size in factor analysis. Psychological Methods, 4(1), 84-99. https://doi.org/10.1037/1082-989X.4.1.84

Maignan, I., Ferrell, O. C., \& Ferrell, L. (2005). A stakeholder model for implementing social responsibility in marketing. European Journal of Marketing, 39(9), 956-977. https://doi.org/10.1108/03090560510610662

Malik, E. M., Naeem, B., \& Nasir, A. M. (2011). Impact of service quality on brand image: Empirical evidence from hotel industry. Interdisciplinary Journal of Contemporary Research in Business, 2(8), 600-636.

Marín, L., Ruiz, S., \& Rubio, A. (2009). The role of identity salience in the effects of corporate social responsibility on consumer behavior. Journal of Business Ethics, 84(1), 65-78. https://doi.org/10.1007/s10551-008-9673-8

Martínez, P., Pérez, A., \& del Bosque, I. R. (2014). CSR influence on hotel brand image and loyalty. Academia Revista Latinoamericana de Administración, 27(2), 267-283.

https://doi.org/10.1108/ARLA-12-2013-0190 
Melewar, T. C., \& Karaosmanoglu, E. (2006). Seven dimensions of corporate identity: A categorisation from the practitioners' perspectives. European Journal of Marketing, 40(7/8), 846-869. https://doi.org/10.1108/03090560610670025

Moliner, M. A., Tirado, D. M., \& Estrada-Guillén, M. (2019). CSR marketing outcomes and branch managers' perceptions of CSR. International Journal of Bank Marketing, 38(1), 63-85. https://doi.org/10.1108/IJBM-11-2018-0307

Nan, X., \& Kwangjun, H. (2007). Consumer responses to corporate social responsibility (CSR) initiatives: Examining the role of brand-cause fit in cause related marketing. Journal of Advertising, 36(2), 63-74. https://doi.org/10.2753/JOA0091-3367360204

Ottman, A. J. (2011). The new rules of green marketing: Strategies, tools and inspiration for sustainable branding. Berrett-Koehler Publisher, Inc.

Park, E. (2019). Corporate social responsibility as a determinant of corporate reputation in the airline industry. Journal of Retailing and Consumer Services, 47, 215-221. https://doi.org/10.1016/j.jretconser.2018.11.013

Rahman, M., Rodríguez-Serrano, M. A., \& Lambkin, M. (2019). Brand equity and firm performance: The complementary role of corporate social responsibility. Journal of Brand Management, 26(6), 691-704. https://doi.org/10.1057/s41262-019-00155-9

Richard, J. E., \& Zhang, A. (2012). Corporate image, loyalty, and commitment in the consumer travel industry. Journal of Marketing Management, 28(5-6), 568-593. https://doi.org/10.1080/0267257X.2010.549195

Saunders, M. N. K., Lewis, P., \& Thornhill, A. (2009). Research methods for business students ( ${ }^{\text {th }}$ ed.). FT Prentice Hall.

Singh, J., \& Saini, S. (2016). Managing consumer loyalty through acquisition, retention and experience efforts: An empirical study on service consumers in India. Vision: The Journal of Business Perspective, 20(2), 121-134. https://doi.org/10.1177/0972262916637264

Slapper, F. T., \& Hall, J. T. (2011). The triple bottom line: What is it and how does it work? Indiana Business Review, 86(1), 4-8.

Sobel, M. E. (1986). Some new results on indirect effects and their standard errors in covariance structure models. Sociological Methodology, 16, 159-186. https://doi.org/10.2307/270922

Suki, N. M., \& Suki, N. M. (2019). Correlations between awareness of green marketing, corporate social responsibility, product image, corporate reputation, and consumer purchase intention. In Management Association, I. (Ed.), Corporate social responsibility: Concepts, methodologies, tools, and applications (pp. 143-154). IGI Global. https://doi.org/10.4018/978-1-5225-6192-7.ch008

Tang, W. W. (2007). Impact of corporate image and corporate reputation on customer loyalty: A review. Management Science and Engineering, 1(2), 57-62.

Werther, W. B. Jr., \& Chandler, D. (2005). Strategic corporate social responsibility as global brand insurance. Business Horizons, 48(4), 317-324. https://doi.org/10.1016/j.bushor.2004.11.009

Windsor, D. (2001). The future of corporate social responsibility. The International Journal of Organizational Analysis, 9(3), 225-256. https://doi.org/10.1108/eb028934

Wu, S. I., \& Wang, W. H. (2014). Impact of CSR perception on brand image, brand attitude and buying willingness: A study of a global café. International Journal of Marketing Studies, 6(6), 43-56. https://doi.org/10.5539/ijms.v6n6p43

Xuan, L. T. T., \& Teal, G. (2011). A development in defining Corporate Social Responsibility. Journal of Science and Technology Development, 14(2), 106-115. https://doi.org/10.32508/stdj.v14i2.1935

Yang, J., \& Basile, K. (2019). The impact of corporate social responsibility on brand equity. Marketing Intelligence \& Planning, 37(1), 2-17. https://doi.org/10.1108/MIP-02-2018-0051

Zulfiqar, S., Sadaf, R., Popp, J., Vveinhardt, J., \& Máté, D. (2019). An examination of corporate social responsibility and employee behavior: The case of Pakistan. Sustainability, 11(13), 3515.

https://doi.org/10.3390/su11133515 